\title{
Amphibole crystallization conditions as record of interaction between ultrapotassic enclaves and monzonitic magmas in the Glória Norte Stock, South of Borborema Province
}

\author{
Vinícius Anselmo Carvalho Lisboa ${ }^{1,2 *}$ (D), Herbet Conceição ${ }^{1,3}$ (D), Maria Lourdes Silva Rosa (D), $^{2}$
} Gisele Tavares Marques ${ }^{4}$ (D) Cláudio Nery Lamarão ${ }^{4}$ (D), André Luiz Rezende Lima ${ }^{3}$ (D)

\begin{abstract}
The Glória Norte Stock (GNS) is made up of predominantly porphyritic biotite- amphibole-bearing quartz monzonite, enclosing a large number of microgranular mafic enclaves (MME). The GNS MME are fine-grained rocks with rounded and ellipsoid shapes that show sharp and gradational contacts with the host rocks, suggesting they coexisted with the host monzonite as magmas. The studied amphibole crystals of the two rock types are calcic and correspond to pargasite, edenite, and magnesium-hornblende. Their compositions are influenced by substitutions involving $\mathrm{Al}^{3+}, \mathrm{Na}^{+}, \mathrm{Fe}^{2+}, \mathrm{Si}^{4+}$ and $\mathrm{Mg}^{2+}$ ions, reflecting the decrease in temperature and the increase in oxygen fugacity. They present low $\mathrm{Ti}$ and $\mathrm{Al}$ contents, and varied $\mathrm{Si}$ content (6.2-7.7 apuf). The $\mathrm{mg \#}$ values range from $0.48-0.84$. Pressures for the crystallization of the MME amphiboles vary between 2.6 and $7.8 \mathrm{kbar}$ and the temperatures of solidus and liquidus were estimated between 600-659 and $887-908^{\circ} \mathrm{C}$, respectively. The early MME amphibole crystals with lower $\mathrm{Si}$ and $\mathrm{Mg}$ content were formed under high pressure (7.8 kbar) and temperature $\left(908^{\circ} \mathrm{C}\right)$. The presence of amphiboles with $862^{\circ} \mathrm{C}$ and $5 \mathrm{kbar}$ in MME and GNS reflects that the interaction between these magmas occurred at $18 \mathrm{~km}$ of depth.
\end{abstract}

KEYWORDS: mineral chemistry; amphibole thermobarometry; Sergipano Orogenic System.

\section{INTRODUCTION}

Amphiboles constitute a complexgroup of rock-forming minerals, which present large compositional variation and occur in several mineral associations. Their structures and chemical compositions are affected by changes in conditions during or after their crystallization (Hawthorne 1983). Amphiboles occur in igneous rocks, from acidic to ultrabasic, and in medium- to high-temperature metamorphic rocks (Deer et al. 1997, Martin 2007). Additionally, the occurrence of amphibole in mafic-ultramafic enclaves associated with granites and basalts indicates that it is stable in the mantle (e.g., Green and Ringwood 1963, Krawczynski et al. 2012).

Granites make up around $25 \%$ of the outcrop area of the Macururé Domain (MD), in the Sergipano Orogenic System

${ }^{1}$ Universidade Federal da Bahia - Salvador (BA) Brazil.

E-mail: vinicius.lisboa@ifpb.edu.br

${ }^{2}$ Instituto Federal de Educação, Ciência e Tecnologia da Paraíba - Picuí (PB), Brazil.

${ }^{3}$ Universidade Federal de Sergipe - São Cristóvão (SE), Brazil. E-mails: herbet@ufs.br; lrosa@ufs.br, luizrezendelima@gmail.com

${ }^{4}$ Universidade Federal do Pará - Belém (PA), Brazil.

E-mails: gisele.ufpa@gmail.com; lamarao@ufpa.br

${ }^{*}$ Corresponding author.

(C) 2020 The authors. This is an open access article distributed under the terms of the Creative Commons license.
(SOS), (Davison and Santos 1989). Conceição et al. (2016) grouped the MD intrusions into four distinct groups:

- High-K calc-alkaline granodiorites;

- Shoshonitic monzonites;

- Leucocratic syenogranites;

- Rapakivi-textured calc-alkaline granites.

Microgranular mafic enclaves (MME) are common in the SOS granites and some of them show high amphibole contents (Sial et al. 1998). The genesis of amphibole enclaves in the MD has been ascribed to the mixing between felsic and mafic magmas (Sial et al. 1998, Conceição et al. 2016, Lisboa et al. 2019). Interaction between magmas with distinct compositions can generate total or partial mixing, and partial corrosion textures in early formed crystals (Barbarin and Didier 1992). The minerals formed during mixing may have their chemical composition modified or rebalanced due to reactions with the hybrid magma (Şahin et al.2010).

This work presents and discusses the result of the chemical analysis obtained on amphibole crystals of microgranular mafic enclaves of the Glória Norte Stock (GNS), their textural relations and crystallization conditions.

\section{GEOLOGICAL CONTEXT}

The SOS defines the N-NE limit of the São Francisco Craton (SFC) (Fig. 1). The formation of the SOS is attributed to the 
neoproterozoic collision between the SFC and the PernambucoAlagoas Superterraine (PEAL; Davison and Santos 1989). According to Oliveira et al. (2010), the convergence between SFC and PEAL led to the deformation of passive margins and granitic plutons emplacement in the central-northern portion of the SOS, during 628-621 and 590-570 Ma. These granites have calc-alkaline and shoshonitic signatures (Silva Filho et al. 1992, Conceição et al. 2016, Lisboa et al. 2019).

The GNS, which was crystallized at $588 \pm 5 \mathrm{Ma}$ (zircon $\left.\mathrm{U}-\mathrm{Pb}_{\text {SHRIMP }}\right)$ is the main representative of the MD post-orogenic shoshonitic magmatism (Lisboa et al. 2019). This stock has an area of $45 \mathrm{~km}^{2}$ (Fig. 1) and is essentially composed of porphyritic quartz-monzonite. Biotite, amphibole, and diopside are the mafic minerals present in these rocks. In quartz-monzonites, the enclaves and feldspar phenocrysts mark a magmatic flow foliation. The GNS contains abundant mafic enclaves, comprising three different types: microgranular mafic, lamprophyric, and cumulatic ultramafic.

The lamprophyric enclaves occur in the midwestern portion of the GNS. They are dark colored with varied shape and their length is up to 1.3 meters, with sharp contacts with quartz-monzonite. The diopside biotite cumulate enclaves (Fontes et al.2018) are medium-grained rocks with olive green color and rounded shape.

MME are abundant in the GNS (Fig. 2A). They have different sizes and shapes (mostly rounded and ellipsoidal), often with the longest axis orientated by the magmatic flow. The contacts of these enclaves with the host quartz monzonitic rocks are gradational or sharp and their cores are more coarse-grained than the border (Fig. 2B). The decreasing grain size toward the edge of the MME is interpreted as resulting from the rapid cooling of the mafic magma droplets, due to temperature contrast with the felsic magma. Color gradation forms darker to lighter MME types, reflecting the mafic mineral contents. This variation is interpreted with different degrees of mixing between magmas. In the felsic magma, the interaction is less pervasive, limited to the contact (a few centimeters) with the mafic magma.

Lisboa et al. (2019) characterized the MME as ultrapotassic alkali feldspar syenite and monzonite rocks ( $44<$ $\% \mathrm{SiO}_{2}<47, \mathrm{MgO}>3 \%, \mathrm{~K}_{2} \mathrm{O}>3 \%$, and $\mathrm{K}_{2} \mathrm{O} / \mathrm{Na}_{2} \mathrm{O}>2$ ). According to these authors, the MME of GNS rocks correspond to intermediate magma, while the composition of the most primitive microgranular mafic enclaves correspond to mafic magmas. The low $\mathrm{Ta}, \mathrm{Nb}$, and Ti contents, which characterize orogenic magmas, are characteristics of both GSN and MME samples.

\section{MATERIALS AND METHODS}

The investigation was executed in polished thin sections of representative samples from the host quartz monzonite and mafic enclaves. The petrographic study was carried out with the aid of a transmitted and reflected light petrographic microscope from the Microscopy Laboratory at the Geoscience Laboratories, Universidade Federal de Sergipe (CLGeo-UFS).

The chemical compositions of the amphibole crystals were obtained from analysis through wavelength dispersion (WDS) and dispersive energy (EDS). The analyses with WDS were performed with the JEOL JXA-8230 electronic probe from the Microanalysis Laboratory, Universidade Federal do Pará

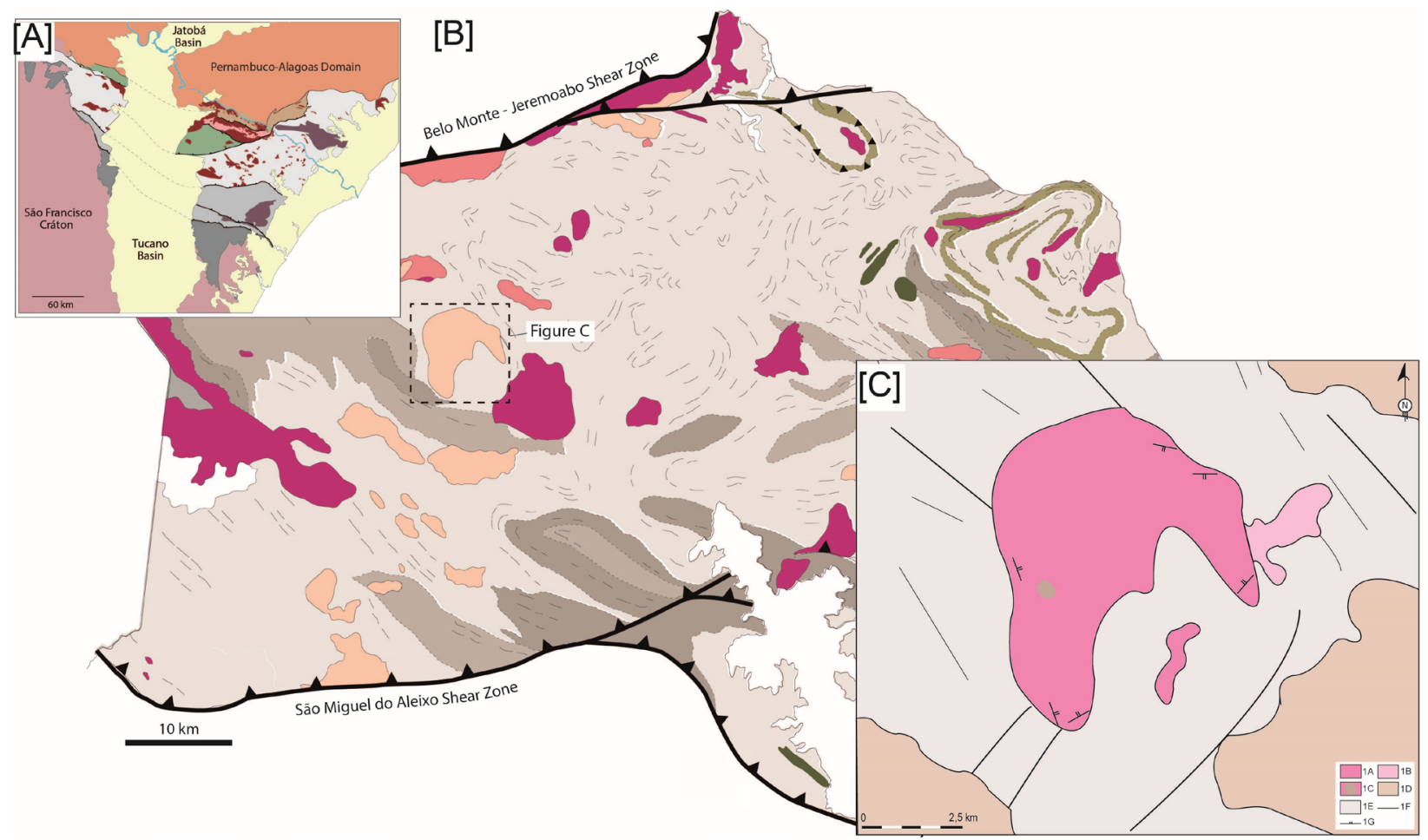

1A: Porphyritic hornblende biotite quartz-monzonite with mafic enclaves; 1B: hornblende biotite monzogranite; 1C: area with the highest incidence of lamprophyric enclaves; 1D: other granites; 1E: metasediments of the Macururé Domain; 1F: aerophotographic lineaments; 1G: magmatic foliation.

Figure 1. (A) Geological compartmentation of the Sergipano Orogenic System (Pinho Neto et al. 2019). (B) Geological sketch map of the Macururé Domain proposed by Conceição et al. 2016. (C) Geological scheme of the Glória Norte Stock (Lisboa et al. 2019). 
(LABMEV-UFPA). Constant accelerating voltage of $15 \mathrm{kV}$, electron beam current of $20 \mathrm{nA}$, electron beam diameter of 10 $\mu \mathrm{m}$, with counting time for the analysis of major and minor elements of 20 and 40 s, respectively. The following calibration standards were used for WDS analysis: fluorite $(\mathrm{F})$, sodalite $\left(\mathrm{Na}_{2} \mathrm{O}\right)$, diopside $(\mathrm{MgO})$, anortite $\left(\mathrm{Al}_{2} \mathrm{O}_{3}\right)$, orthoclase $\left(\mathrm{SiO}_{2}\right.$, $\left.\mathrm{K}_{2} \mathrm{O}\right)$, wollastonite $(\mathrm{CaO})$, celestine $(\mathrm{SrO})$, magnetite $(\mathrm{FeO})$, rhodonite $(\mathrm{MnO})$, barite $(\mathrm{BaO})$, rutile $\left(\mathrm{TiO}_{2}\right)$, sodalite $(\mathrm{Cl})$, vanadinite $\left(\mathrm{V}_{2} \mathrm{O}_{3}\right), \mathrm{Cr}_{2} \mathrm{O}_{3}\left(\mathrm{Cr}_{2} \mathrm{O}_{3}\right)$, and $\mathrm{NiO}(\mathrm{NiO})$.

EDS analysis was performed with an Oxford Instrument ${ }^{\circledR}$ X-Act model EDS attached to a Tescan ${ }^{\circledR}$ Scanning Electron Microscope (SEM) Vega 3 LMU model at the Laboratory of Microanalysis, Universidade Federal de Sergipe (CLGeo-UFS). Potential acceleration of $20 \mathrm{kV}$ and current intensity of $17 \mathrm{nA}$, generating a beam with a diameter of $400 \mathrm{~nm}$; analysis time was $30 \mathrm{~s}$. The CLGeo's EDS-SEM is calibrated with copper energy and the reliability of the analyses is assessed from the analysis of ASTIMEX international mineral standards (Tab. 1). The analytical uncertainties, given by the difference between the certified values and those obtained with the EDS, were less than $2 \% \mathrm{wt}$ for the elements with content greater than $10 \% \mathrm{wt}$ in weight and errors between 4 and 19\%wt for elements with content below $5 \%$ in weight.

\section{RESULTS}

\section{Petrographic aspects}

The MME studied correspond to alkali feldspar syenites and monzonites that exhibit fine- to medium-grained or equigranular porphyritic texture. The essential mineralogy of these enclaves is: amphibole, biotite, plagioclase (andesine and oligoclase), alkali feldspar and quartz (Fig. 3). Accessory minerals are diopside, epidote, allanite, titanite, apatite, zircon, ilmenite, magnetite, pyrite, and chalcopyrite.

Green amphibole is the dominant mafic phase in the MME (up to 53\% volume). Most crystals are subhedral with a length of up to $1.5 \mathrm{~mm}$. Pleochroism ranges between olive green $\left(\mathrm{Y}^{\prime}\right)$, yellowish green $\left(\mathrm{Z}^{\prime}\right)$ to light yellowish green $\left(\mathrm{X}^{\prime}\right)$. The grain limits with most minerals are rectilinear and irregular to interpenetrating with biotite and diopside. It shows inclusions of anhedral quartz, subhedral biotite, as well as apatite and ilmenite euhedral grains. Green amphibole is replaced by colorless amphibole at the borders.

The amphibole crystals are well distributed in the MME. They occur as grains up to $0.5 \mathrm{~mm}$, as subhedral to anhedral crystals in mafic agglomerates, as well as euhedral inclusions in alkali feldspar and, more rarely, in plagioclase.

Mafic minerals such as amphibole, diopside, titanite, ilmenite, and magnetite, occur as agglomerates with up to $3.0 \mathrm{~mm}$ in length. Diopside is anhedral and rimmed by dark green amphibole (Fig. 4A). The limits between diopside and amphibole grains are diffuse and the diopside cleavage planes contain subhedral grains of ilmenite and magnetite. The association of amphibole with biotite is more common. In this case, biotite occurs as subhedral crystals with size up to $0.8 \mathrm{~mm}$, arranged between amphibole crystals (Fig. 4B) or along their cleavage planes.

Lisboa et al. (2019) described abundant crystals of stubby apatite and mafic mineral agglomerates, composed by amphibole, biotite, and diopside, in the GNS porphyritic quartz monzonite. Baxter and Feely (2002) propose that agglomerates of this nature are formed from a reaction between pyroxene and magma, thus leading to crystallization of amphibole. The occurrence of these agglomerates in the studied rocks suggests that they originated from mafic magma, which was responsible for the formation of MME, and their presence in the GNS enclaves and monzonites is interpreted as due to the interaction between felsic and mafic magmas, or could be only due to equilibrium crystallization of the quartz monzonite magma.

\section{Mineral chemistry}

\section{Nomenclature and chemical composition}

Chemical classification of the amphiboles and structural formula were based on 23 oxygens, assuming the general formula $\mathrm{A}_{0-1} \mathrm{~B}_{2} \mathrm{C}_{5} \mathrm{~T}_{8} \mathrm{O}_{22}(\mathrm{OH}, \mathrm{F}, \mathrm{Cl})$, whose site occupation complied with the recommendations of Leake et al. (1997). In total, 60 amphibole crystals were analyzed. Representative chemical analyses of these crystals are presented in Table 2.
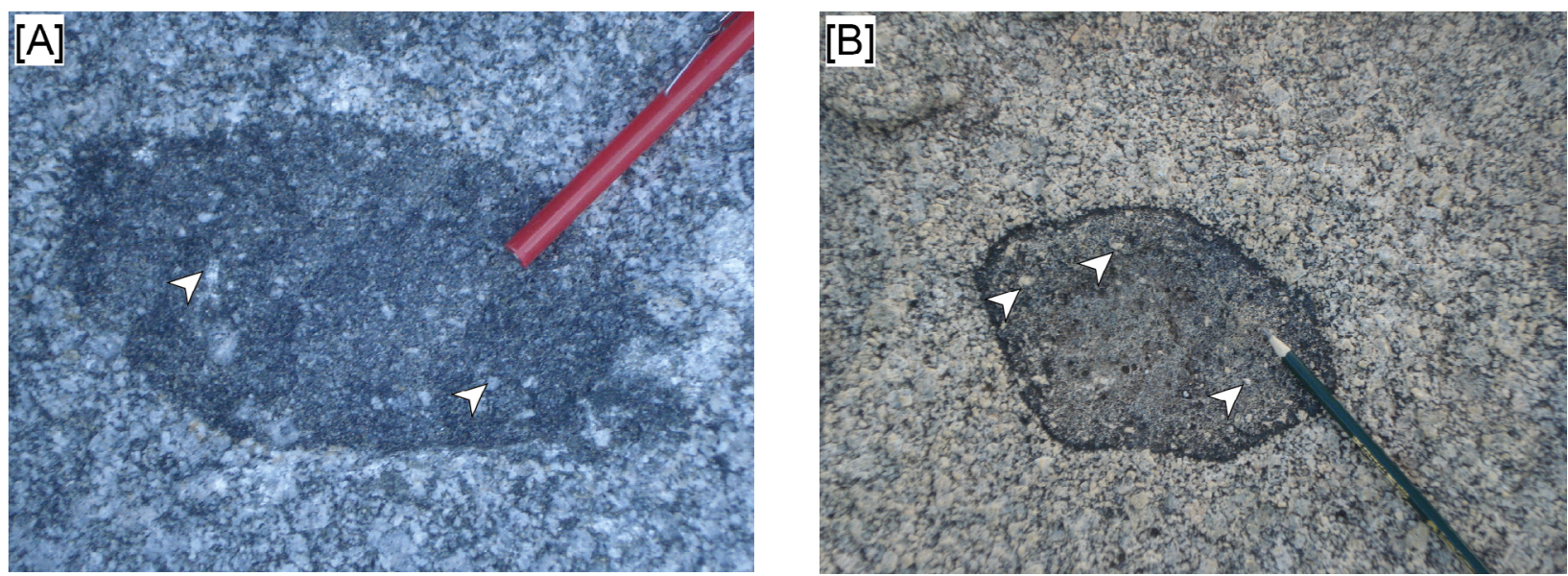

Figure 2. Field aspects of the studied enclaves. (A) Dark-colored MME with ellipsoidal shape. Note the finer grain size as compared to the host porphyritic monzonite. The white arrow marks the feldspar xenocrysts. (B) Microgranular mafic enclave correspond to alkali feldspar syenite and is composed of biotite and amphibole with a finer-grained border (with darker coloration) as well as feldspar xenocrysts (white arrow). 
The MME amphibole crystals are calcic, with $\mathrm{Ca}_{\mathrm{B}}$ content between 1.5-2.0 apuf (atoms per unit formula), and can be divided into two groups (Figs. 5A and 5B):

- $(\mathrm{Na}+\mathrm{K})_{\mathrm{A}}>0.5$ apuf (pargasite and edenita);

- $(\mathrm{Na}+\mathrm{K})_{\mathrm{A}}<0.5$ apuf(magnesium-hornblende and actinolite).

These amphiboles show mg\# $\left[\mathrm{Mg}^{2+} /\left(\mathrm{Mg}^{2+}+\mathrm{Fe}^{2+}\right)\right]$ ratios ranging from $0.48-0.84 . \mathrm{TiO}_{2}(0.0-2.0 \%), \mathrm{Al}_{2} \mathrm{O}_{3}(3.9-12.3 \%)$, $\mathrm{FeO}(5.0-16.0 \%), \mathrm{MgO}(9.0-15.4 \%), \mathrm{MnO}(0.0-0.4 \%)$, $\mathrm{CaO}(10.0-12.4 \%), \mathrm{Na}_{2} \mathrm{O}(0.5-1.9 \%)$, and $\mathrm{K}_{2} \mathrm{O}(0.2-3.8 \%)$. The intermediate contents of $\mathrm{SiO}_{2}$ and low $\mathrm{TiO}_{2}$ and alkali $\left(\mathrm{Na}_{2} \mathrm{O}\right)$ contents are similar to those of amphiboles found in rocks formed in orogenic environments (Coltorti et al. 2007, Martin 2007).
In some amphibole crystals, the increase in $\mathrm{Si}$ and $\mathrm{Mg}$ associated with the depletion in ${ }^{\mathrm{IV}} \mathrm{Al}$ from nucleus to border, form actinolite (Fig. 5B). The existence of such zoning may be a consequence of the increased oxygen fugacity in the magma, or it may also result from the reaction between magmatic amphibole and late fluids (Kawakatsu and Yamaguchi 1987, Martin 2007). Similar zoning is also described as evidence of mixing between magmas by Sato et al. (1999).

Calcium amphiboles are also important mafic minerals in the GNS monzonites, where they reach up to $14 \%$ of the volume (Lisboa et al.2019). Analyzes from representative samples of the GNS revealed that amphibole crystals from this stock correspond to edenite (Fig. 5A) and to magnesium-hornblende (Fig. 5B). There is an overlap among samples of the GSN and MME.

Table 1. Comparison between the composition of ASTIMEX reference standards and the results obtained through the EDS, adapted from Leandro (2018).

\begin{tabular}{|c|c|c|c|c|c|c|c|c|c|c|c|c|}
\hline & \multicolumn{3}{|c|}{ Biotite } & \multicolumn{3}{|c|}{ Diopside } & \multicolumn{3}{|c|}{ Kaersutite } & \multicolumn{3}{|c|}{ Sanidine } \\
\hline & 1 & 2 & 3 & 1 & 2 & 3 & 1 & 2 & 3 & 1 & 2 & 3 \\
\hline $\mathrm{SiO}_{2}$ & 38.72 & 39.05 & 0.33 & 55.13 & 55.36 & 0.23 & 40.09 & 40.12 & 0.03 & 64.67 & 64.58 & 0.09 \\
\hline $\mathrm{TiO}_{2}$ & 1.77 & 1.54 & 0.23 & 0.05 & 0.14 & 0.09 & 5.04 & 5.61 & 0.57 & & & \\
\hline $\mathrm{Cr}_{2} \mathrm{O}_{3}$ & & & & 0.58 & 0.54 & 0.04 & & & & & & \\
\hline $\mathrm{Al}_{2} \mathrm{O}_{3}$ & 15.30 & 15.27 & 0.03 & & & & 12.36 & 13.07 & 0.71 & 18.76 & 18.92 & 0.16 \\
\hline $\mathrm{FeO}$ & 10.72 & 9.53 & 1.19 & 1.21 & 1.32 & 0.11 & 12.23 & 11.36 & 0.87 & 0.18 & 0.34 & 0.16 \\
\hline $\mathrm{MnO}$ & 0.04 & 0.13 & 0.09 & & & & 0.18 & 0.16 & 0.02 & & & \\
\hline $\mathrm{MgO}$ & 19.52 & 20.34 & 0.82 & 17.46 & 17.90 & 0.44 & 12.55 & 12.95 & 0.40 & & & \\
\hline $\mathrm{CaO}$ & 0.10 & 0.10 & 0.00 & 25.55 & 24.82 & 0.73 & 11.56 & 11.32 & 0.24 & & & \\
\hline $\mathrm{BaO}$ & & & & & & & & & & 1.09 & 1.26 & 0.17 \\
\hline $\mathrm{Na}_{2} \mathrm{O}$ & & & & & & & 2.44 & 2.51 & 0.07 & 3.01 & 2.90 & 0.11 \\
\hline $\mathrm{K}_{2} \mathrm{O}$ & 9.91 & 10.05 & 0.14 & & & & 1.19 & 0.96 & 0.23 & 12.11 & 12.14 & 0.03 \\
\hline Total & 96.08 & 96.01 & & 99.98 & 100.08 & & 97.62 & 98.06 & & 98.82 & 100.14 & \\
\hline
\end{tabular}

1: ASTIMEX standard; 2: analyses accomplished with the EDS; 3: difference between oxide content in standard and the one dosed by EDS.

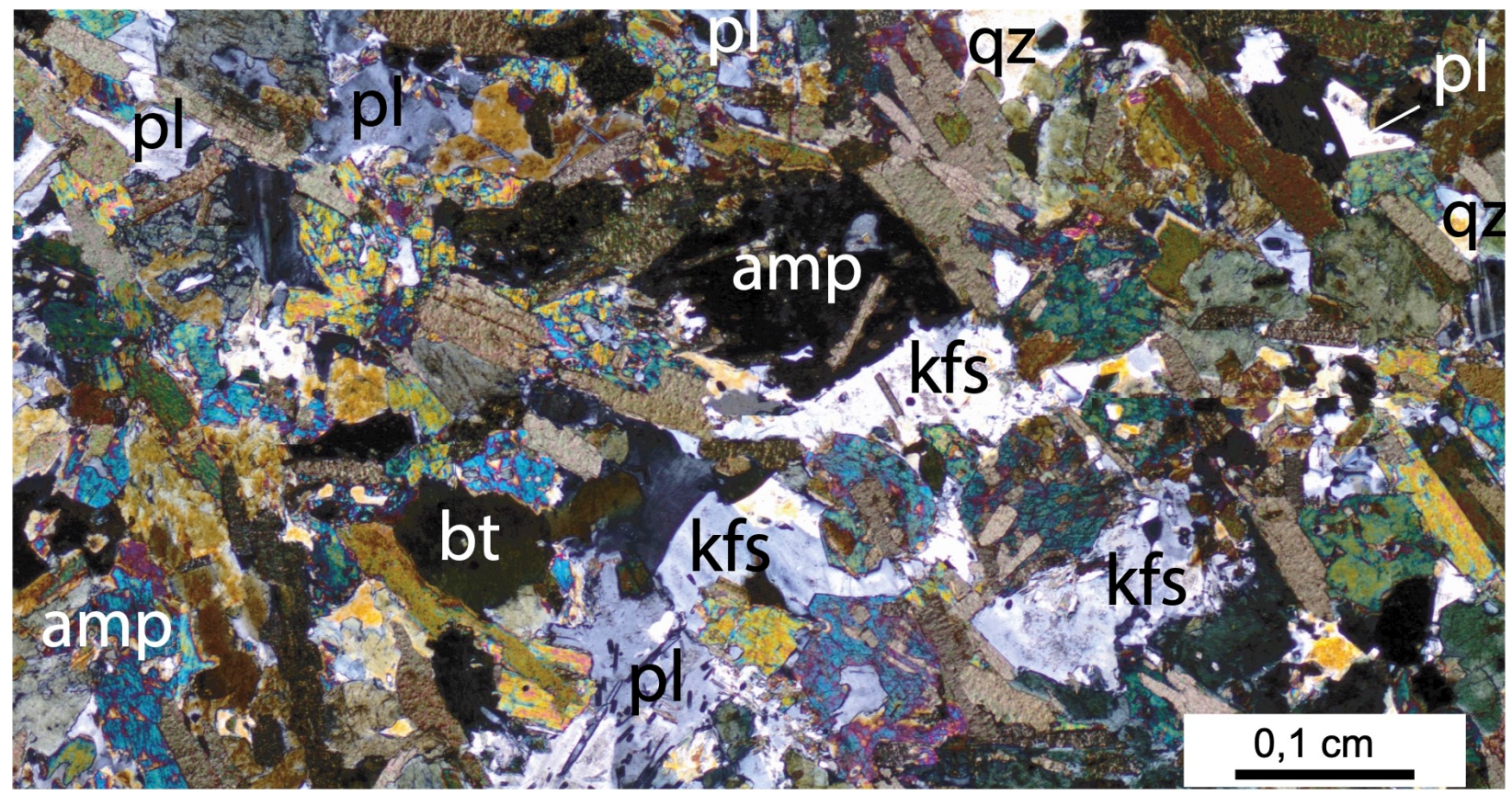

bt: biotite; amp: amphibole; ep: epidote; ap: apatite; qz: quartz; kfs: alkaline feldspar; pl: plagioclase.

Figure 3. Representative texture of the microgranular mafic enclaves of the Glória Norte Stock. It is possible to observe a fine- to mediumgrained granular rock. 

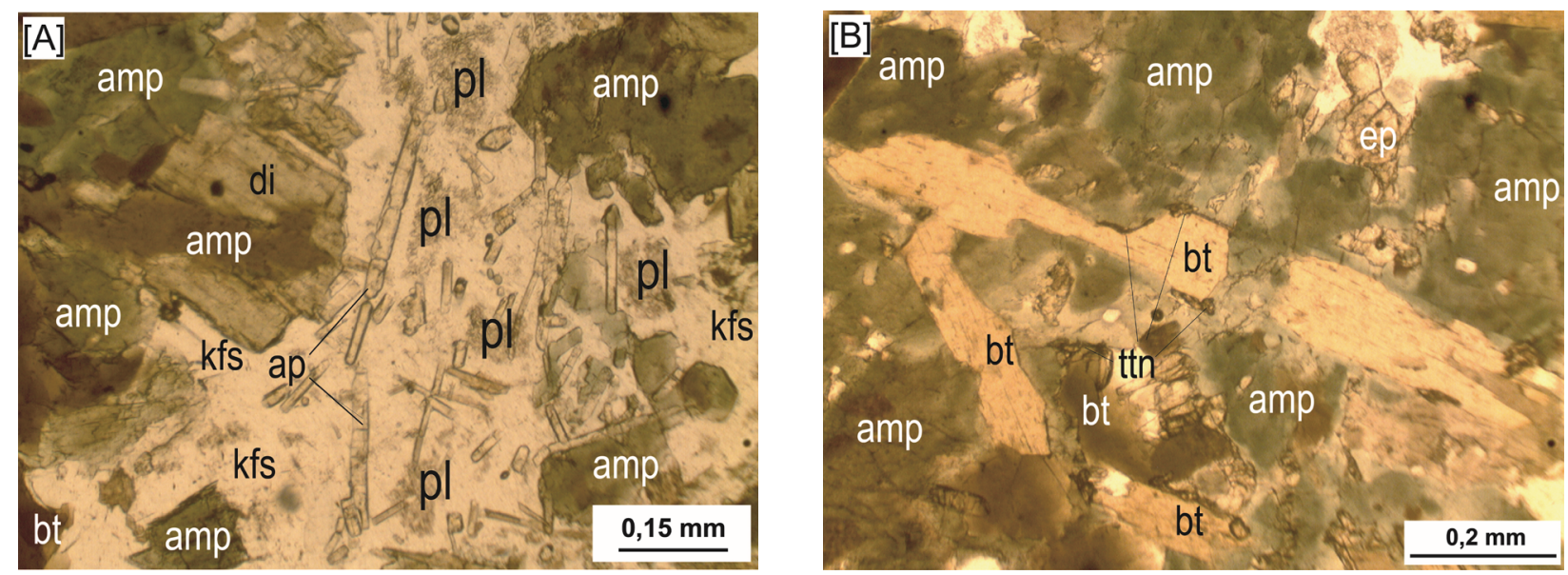

amp: amphibole; di: diopside; bt: biotite; ep: epidote; ttn: titanite; kfs: alkaline feldspar; pl: plagioclase.

Figure 4. Photomicrography of the GNS microgranular mafic enclaves. (A) Contact relationships between amphibole and diopside grains. Also note the presence of subhedral amphibole and stubby apatite crystals included in alkali feldspar; (B) Subhedral biotite crystals between amphibole crystals.

Table 2. Representative chemical analyses of the studied amphiboles. The $\mathrm{Fe}^{2+} / \mathrm{Fe}^{3+}$ partition was made using the Stout's method (1972). $\mathrm{H}_{2} \mathrm{O}^{*}$ was calculated by stoichiometry.

\begin{tabular}{|c|c|c|c|c|c|c|c|c|c|c|c|c|c|c|c|c|c|c|}
\hline \multirow{2}{*}{$\begin{array}{l}\text { Facies } \\
\text { Sample }\end{array}$} & \multicolumn{14}{|c|}{ MME } & \multicolumn{4}{|c|}{ GNS } \\
\hline & $12 B_{2}$ & $12 B_{2}$ & $12 B_{2}$ & $12 B_{2}$ & 3AF & $3 \mathrm{AF}$ & $3 \mathrm{AF}$ & $3 \mathrm{AF}$ & $3 F$ & $3 F$ & $3 \mathbf{U}$ & $3 \mathbf{U}$ & $12 B_{4}$ & $12 B_{4}$ & 03A & 03A & 192 & 192 \\
\hline Analise & 9 & 10 & 14 & 15 & 3 & 4 & 5 & 6 & 120 & 121 & 13 & 14 & 66 & 67 & 1 & 8 & 17 & 19 \\
\hline Position & core & rim & core & rim & core & rim & core & rim & rim & core & core & rim & core & rim & core & rim & core & rim \\
\hline $\mathrm{SiO}_{2}$ & 41.61 & 42.05 & 41.85 & 46.16 & 40.92 & 44.93 & 42.43 & 43.94 & 52.14 & 45.47 & 46.16 & 45.57 & 44.30 & 44.10 & 45.18 & 46.16 & 44.30 & 50.96 \\
\hline $\mathrm{TiO}_{2}$ & 2.01 & 1.46 & 1.96 & 0.69 & 1.26 & 0.72 & 1.08 & 0.76 & & 0.78 & 0.78 & 0.78 & 1.08 & 0.98 & 1.57 & 0.59 & 1.67 & 0.10 \\
\hline $\mathrm{Al}_{2} \mathrm{O}_{3}$ & 12.34 & 12.02 & 12.35 & 11.56 & 10.96 & 9.68 & 11.64 & 10.15 & 3.92 & 9.02 & 8.92 & 8.82 & 9.90 & 10.09 & 9.11 & 8.72 & 9.80 & 5.29 \\
\hline $\mathrm{Cr}_{2} \mathrm{O}_{3}$ & & 0.01 & & & 0.02 & 0.04 & 0.08 & 0.13 & & & & & & & & & & \\
\hline $\mathrm{Fe}_{2} \mathrm{O}_{3}$ & 1.97 & 2.46 & 3.24 & 8.03 & 3.14 & 3.09 & 3.53 & 3.16 & 3.78 & 4.77 & 3.65 & 4.54 & 5.27 & 3.37 & 2.40 & 1.61 & 3.22 & 3.56 \\
\hline $\mathrm{FeO}$ & 14.47 & 14.28 & 13.75 & 5.61 & 14.74 & 13.88 & 14.18 & 14.23 & 9.44 & 11.98 & 12.20 & 12.08 & 12.80 & 14.22 & 13.91 & 15.21 & 14.06 & 10.02 \\
\hline $\mathrm{MnO}$ & 0.37 & 0.32 & 0.49 & 0.29 & 0.40 & 0.42 & 0.45 & 0.41 & 0.29 & 0.29 & 0.49 & 0.39 & 0.29 & 0.39 & 0.29 & 0.29 & 0.29 & 0.39 \\
\hline $\mathrm{MgO}$ & 9.83 & 9.82 & 9.90 & 13.23 & 9.05 & 10.70 & 9.56 & 10.15 & 15.48 & 11.86 & 11.96 & 11.86 & 10.68 & 10.49 & 11.27 & 10.98 & 10.68 & 14.60 \\
\hline $\mathrm{CaO}$ & 11.55 & 11.51 & 11.47 & 10.09 & 11.20 & 11.61 & 11.34 & 11.45 & 12.15 & 11.56 & 11.86 & 11.56 & 11.27 & 11.47 & 11.47 & 11.76 & 11.37 & 11.96 \\
\hline $\mathrm{Na}_{2} \mathrm{O}$ & 1.91 & 1.75 & 1.86 & 2.06 & 1.67 & 1.58 & 1.76 & 1.64 & 0.69 & 1.67 & 1.37 & 1.67 & 1.76 & 1.86 & 1.76 & 1.67 & 1.86 & 0.98 \\
\hline $\mathrm{K}_{2} \mathrm{O}$ & 1.51 & 1.54 & 1.57 & 1.08 & 1.50 & 1.12 & 1.51 & 1.28 & 0.49 & 1.08 & 0.98 & 1.08 & 1.08 & 1.37 & 1.18 & 1.08 & 1.18 & 0.49 \\
\hline $\mathrm{BaO}$ & 0.09 & 0.18 & & & & 0.08 & 0.02 & & & & & & & & & & & \\
\hline $\mathrm{SrO}$ & 0.02 & 0.05 & & & 0.04 & & 0.03 & 0.04 & & & & & & & & & & \\
\hline $\mathrm{NiO}$ & & & & & 0.02 & & 0.01 & 0.03 & & & & & & & & & & \\
\hline Total & 97.57 & 97.21 & 98.42 & 98.80 & 94.85 & 97.76 & 97.54 & 97.30 & 98.38 & 98.48 & 98.37 & 98.36 & 98.43 & 98.34 & 98.14 & 98.06 & 98.42 & 98.36 \\
\hline $\mathrm{Si}$ & 6.274 & 6.355 & 6.255 & 6.593 & 6.385 & 6.702 & 6.401 & 6.617 & 7.462 & 6.701 & 6.784 & 6.725 & 6.572 & 6.580 & 6.705 & 6.864 & 6.585 & 7.325 \\
\hline $\mathrm{Al}^{\mathrm{IV}}$ & 1.726 & 1.645 & 1.745 & 1.407 & 1.615 & 1.298 & 1.599 & 1.383 & 0.538 & 1.299 & 1.216 & 1.275 & 1.428 & 1.420 & 1.295 & 1.136 & 1.415 & 0.675 \\
\hline Sum $\mathrm{T}$ & 8.000 & 8.000 & 8.000 & 8.000 & 8.000 & 8.000 & 8.000 & 8.000 & 8.000 & 8.000 & 8.000 & 8.000 & 8.000 & 8.000 & 8.000 & 8.000 & 8.000 & 8.000 \\
\hline $\mathrm{Al}^{\mathrm{VI}}$ & 0.468 & 0.495 & 0.430 & 0.540 & 0.402 & 0.404 & 0.471 & 0.417 & 0.124 & 0.267 & 0.329 & 0.259 & 0.303 & 0.356 & 0.300 & 0.392 & 0.302 & 0.222 \\
\hline $\mathrm{Fe}^{3+}$ & 0.224 & 0.279 & 0.364 & 0.863 & 0.369 & 0.347 & 0.400 & 0.358 & 0.407 & 0.529 & 0.403 & 0.505 & 0.589 & 0.378 & 0.268 & 0.180 & 0.360 & 0.385 \\
\hline $\mathrm{Ti}$ & 0.227 & 0.166 & 0.220 & 0.074 & 0.148 & 0.081 & 0.123 & 0.086 & & 0.087 & 0.087 & 0.087 & 0.120 & 0.110 & 0.175 & 0.066 & 0.186 & 0.011 \\
\hline $\mathrm{Cr}$ & & 0.001 & & & 0.003 & 0.004 & 0.009 & 0.016 & & & & & & & & & & \\
\hline $\mathrm{Fe}^{2+}$ & 1.825 & 1.804 & 1.718 & 0.670 & 1.923 & 1.731 & 1.789 & 1.792 & 1.130 & 1.476 & 1.500 & 1.491 & 1.588 & 1.774 & 1.727 & 1.891 & 1.748 & 1.205 \\
\hline $\mathrm{Mn}$ & 0.047 & 0.041 & 0.062 & 0.036 & 0.052 & 0.052 & 0.057 & 0.052 & 0.036 & 0.037 & 0.061 & 0.049 & 0.037 & 0.050 & 0.037 & 0.037 & 0.037 & 0.048 \\
\hline $\mathrm{Mg}$ & 2.210 & 2.213 & 2.205 & 2.817 & 2.104 & 2.380 & 2.150 & 2.279 & 3.304 & 2.605 & 2.620 & 2.609 & 2.363 & 2.333 & 2.494 & 2.433 & 2.367 & 3.129 \\
\hline Sum C & 5.000 & 5.000 & 5.000 & 5.000 & 5.000 & 5.000 & 5.000 & 5.000 & 5.000 & 5.000 & 5.000 & 5.000 & 5.000 & 5.000 & 5.000 & 5.000 & 5.000 & 5.000 \\
\hline $\mathrm{Ca}$ & 1.865 & 1.863 & 1.836 & 1.545 & 1.872 & 1.856 & 1.833 & 1.848 & 1.864 & 1.826 & 1.867 & 1.829 & 1.792 & 1.833 & 1.823 & 1.874 & 1.811 & 1.841 \\
\hline $\mathrm{Na}$ & 0.135 & 0.137 & 0.164 & 0.455 & 0.128 & 0.144 & 0.167 & 0.152 & 0.136 & 0.174 & 0.133 & 0.171 & 0.208 & 0.167 & 0.508 & 0.480 & 0.537 & 0.273 \\
\hline Sum B & 2.000 & 2.000 & 2.000 & 2.000 & 2.000 & 2.000 & 2.000 & 2.000 & 2.000 & 2.000 & 2.000 & 2.000 & 2.000 & 2.000 & 2.000 & 2.000 & 2.000 & 2.000 \\
\hline $\mathrm{Na}$ & 0.425 & 0.377 & 0.376 & 0.115 & 0.377 & 0.312 & 0.349 & 0.327 & 0.054 & 0.302 & 0.258 & 0.305 & 0.299 & 0.372 & 0.331 & 0.354 & 0.347 & 0.115 \\
\hline $\mathrm{K}$ & 0.289 & 0.297 & 0.299 & 0.196 & 0.298 & 0.213 & 0.290 & 0.246 & 0.089 & 0.203 & 0.184 & 0.203 & 0.204 & 0.261 & 0.223 & 0.204 & 0.223 & 0.090 \\
\hline $\mathrm{Ba}$ & 0.010 & 0.021 & & & & 0.009 & 0.002 & & & & & & & & & & & \\
\hline $\mathrm{Sr}$ & 0.004 & 0.009 & & & 0.006 & & 0.005 & 0.006 & & & & & & & & & & \\
\hline $\mathrm{Ni}$ & & & & & 0.006 & & 0.001 & 0.008 & & & & & & & & & & \\
\hline Sum A & 0.728 & 0.703 & 0.675 & 0.311 & 0.686 & 0.534 & 0.647 & 0.587 & 0.143 & 0.504 & 0.442 & 0.508 & 0.503 & 0.633 & 0.554 & 0.558 & 0.570 & 0.204 \\
\hline mg\# & 0.55 & 0.55 & 0.56 & 0.81 & 0.52 & 0.58 & 0.55 & 0.56 & 0.75 & 0.64 & 0.64 & 0.64 & 0.60 & 0.57 & 0.59 & 0.56 & 0.58 & 0.72 \\
\hline
\end{tabular}

$\mathrm{mg} \#=\mathrm{Mg} /\left(\mathrm{Mg}+\mathrm{Fe}^{2+}\right)$ 
Leake (1971, 1978) used the relationship between Si and $(\mathrm{Na}+\mathrm{Ca}+\mathrm{K})$, to distinguish magmatic from post-magmatic amphiboles. Using these criteria, it is clear that some compositions in the MME amphiboles evolve from the magmatic to the post-magmatic field (Fig. 6). Crystals with higher Si content ( $>$ 7.1 apuf) are also enriched in $\mathrm{Mg}$, depleted in $\mathrm{Na}+$ $\mathrm{Ca}+\mathrm{K}(<2.4$ apuf $)$ and present similar compositional variation to that observed by Yamaguchi (1985) for late-crystallized crystals, which had their chemical compositions partially modified due to reactions with magma, or formed under subsolidus conditions in the presence of fluids (Chivas 1982, Hendry et al. 1985).

\section{Substitutions}

Spear (1981) listed the most common amphibole substitutions. The compositional variations in the MME studied crystals can be described in terms of pargasite, tschermakite, and Ti-tschermakite substitutions, in addition to the simple replacement of $\mathrm{Fe}^{2+}$ by $\mathrm{Mg}$ (Spear 1981).

The diagram in Figure 7A shows a good positive correlation between $\left(\mathrm{Na}_{\mathrm{A}}+\mathrm{K}_{\mathrm{A}}\right)$ and ${ }^{\mathrm{IV}} \mathrm{Al}$ for MME amphiboles. The relationship shown in this diagram is close to the $2: 1$ ratio, implying the predominance of pargasite substitution, indicating that the partial occupation of site $\mathrm{A}$ by alkalis requires the replacement of $\mathrm{Si}$ for ${ }^{\mathrm{IV}} \mathrm{Al}$ at the tetrahedral site. The highest vacancy rates at site $[\mathrm{A}]$ are observed for the crystals with higher $\mathrm{Mg}$ and $\mathrm{Si}$ contents. The ${ }^{\mathrm{IV}} \mathrm{Al}$ versus ${ }^{\mathrm{VI}} \mathrm{Al}$ ratio (Fig. $7 \mathrm{~B}$ ) demonstrates the importance of edenite and pargasite substitutions in the evolution of the studied MME amphibole compositions. The inverse behavior of $\mathrm{Fe}$ and $\mathrm{Mg}$ suggests important participation in the simple substitution $\mathrm{Fe}^{+2} \leftrightarrow \mathrm{Mg}$, and also shows the good negative correlation existent between these elements (Fig. 7C).
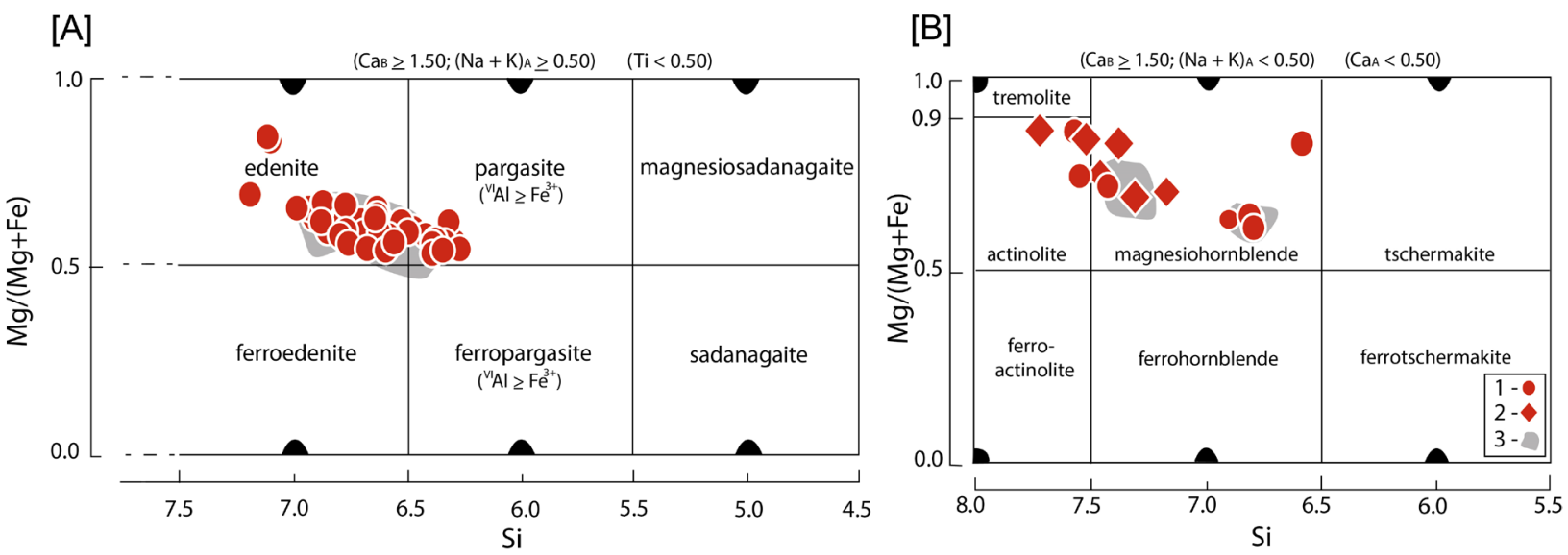

Figure 5. Classification diagrams for the studied calcic amphiboles, after Leake et al. (1997). (1) The composition of the crystal core corresponds to the circle, and (2) the rim corresponds to the diamond. (3) The grey area represents amphiboles from the Glória Norte Stock.

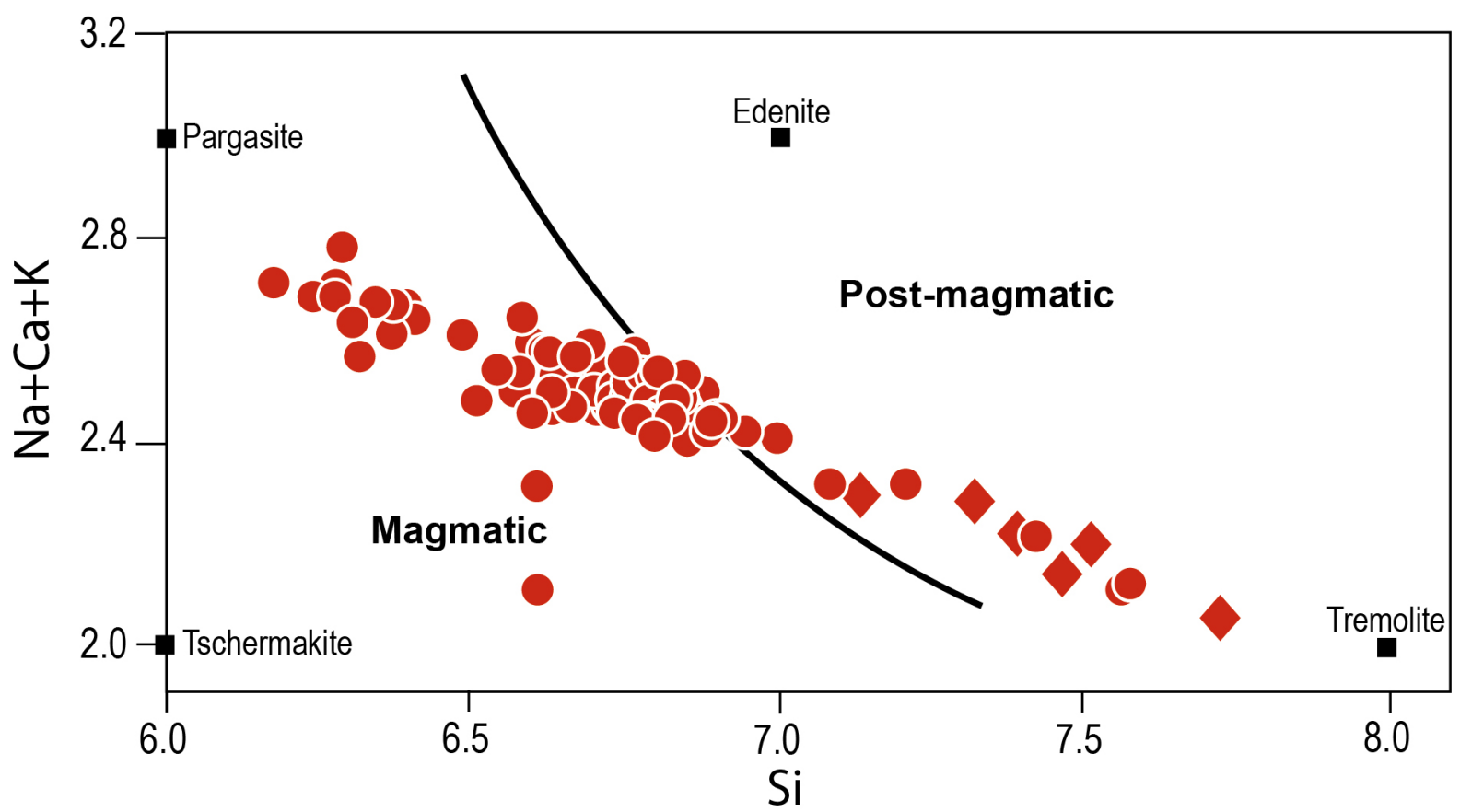

Core: circle; rim: diamond.

Figure 6. Si versus $\mathrm{Na}+\mathrm{Ca}+\mathrm{K}$ diagram of Leake (1971) applied to the studied MME amphibole. The curve separates the compositions of magmatic from post-magmatic amphiboles. 


\section{Conditions of crystallization}

Several studies used amphibole composition to infer pressure (e.g., Schmidt 1992, Mutch et al. 2016), temperature (e.g., Holland and Blundy 1994, Putirka 2016), and oxygen fugacity (e.g., Anderson and Smith 1995) magma conditions of crystallization. In calcium amphiboles, with increased pressure and temperature, $\mathrm{K}, \mathrm{Na}, \mathrm{Ti}$, and $\mathrm{Al}$ contents are generally increased, although $\mathrm{Al}$ is more sensitive to changes in pressure (Hammarstron and Zen 1986, Féménias et al. 2006, Nandedkar et al. 2014)

The main calcium amphibole geobarometers are based on the existence of a linear relationship between ${ }^{\text {total }} \mathrm{Al}$ and crystallization pressure (Anderson 1996). The identification of the amphibole in association with biotite, titanite, magnetite (and/or ilmenite), quartz, alkaline feldspar, and plagioclase in the studied MME allowed the use of these geobarometers. Pressure values calculated for the studied amphiboles by different algorithms are presented in Table 3.

The $\mathrm{Al}^{\mathrm{total}}$ content in the analyzed crystals ranges from 1.42 to 2.22 apuf. Considering all calibrations, the pressures $(\mathrm{P})$ obtained to magmatic amphiboles range from 2.6 to $7.8 \mathrm{kbar}$, corresponding to high- and low-pressure amphiboles (Fig. 8A), according to Hammarstron and Zen (1986). The identification of both high- and low-pressure amphiboles in orogenesis-associated magmas is described in several papers (e.g., Samaniego et al. 2010, Ribeiro et al. 2016).

As demonstrated by Anderson and Smith (1995), the increase of $\mathrm{Al}^{\text {total }}$ may also be related to the increase in temperature. In this case, these authors recommended the use of barometers that consider the effect of temperature. When applying the calibration proposed by Anderson and Smith (1995) in the studied MME amphiboles, it is seen that the pressure values range from 3.8 to $6.6 \mathrm{kbar}$, similarly or very close to those obtained using other calibrations (Tab. 3).

The MME solidus temperature estimates were obtained from the amphibole-plagioclase pair thermometry, which is based on the amount of ${ }^{\mathrm{IV}} \mathrm{Al}$ in the amphibole coexisting with plagioclase in silica-saturated rocks. The results can be seen in Table 4.

The crystallization temperature for the studied MME amphiboles uses the calibration made by Holland and Blundy (1994) for the edenite-richterite reaction. The temperatures were calculated based on the pressures obtained by the Schmidt (1992) and Anderson and Smith (1995) barometers. The temperature values obtained from this geothermometer are situated between 600 and $659^{\circ} \mathrm{C}$ (Tab. 4), below the temperature of the granite solidus, which is around $700^{\circ} \mathrm{C}$ (Piwinskii 1968, McDowell and Willye 1971).

The composition of the cores of the MME pargasite crystals was used to estimate the temperature using the empirical geothermometer of Ridolfi et al. (2010). The temperatures obtained range from 887 to $908^{\circ} \mathrm{C}$ (Tab. 4).

The $\mathrm{fO}_{2}$ has a strong chemical control over major mafic phases in igneous rocks (Anderson and Smith 1995). The studied amphiboles show $\mathrm{Fe} /(\mathrm{Fe}+\mathrm{Mg})$ ratios below 0.6. When these ratios are correlated to the ${ }^{\mathrm{IV}} \mathrm{Al}$ content of the MME and

Table 3. Geobarometry data obtained for the studied MME amphiboles. $\mathrm{P}^{1}$ (Hammarstron and Zen 1986); $\mathrm{P}^{2}$ (Hollister et al. 1987); $\mathrm{P}^{3}$ (Johnson and Rutherford 1989); $\mathrm{P}^{4}$ (Schmidt 1992); $\mathrm{P}^{5}$ (Anderson and Smith 1995); $\mathrm{P}^{6}$ (Mutch et al. 2016).

\begin{tabular}{ccccccc}
\hline \multicolumn{5}{c}{ Pressure (kbar) } \\
\hline $\mathrm{Al}^{\text {total }}($ apuf $)$ & $\mathrm{P}^{1}$ & $\mathrm{P}^{2}$ & $\mathrm{P}^{3}$ & $\mathrm{P}^{4}$ & $\mathrm{P}^{5}$ & $\mathrm{P}^{6}$ \\
$1.42-2.22$ & $3.2-7.3$ & $3.3-7.8$ & $2.6-5.9$ & $3.8-7.6$ & $3.8-6.6$ & $3.0-7.4$ \\
\hline
\end{tabular}

Table 4. Temperature data obtained for the studied MME amphiboles.

\begin{tabular}{cccc}
\hline \multicolumn{4}{c}{ Temperature $\left({ }^{\circ} \mathbf{C}\right)$} \\
\hline $\mathrm{X}_{(\mathrm{An})}$ & $\mathrm{T}_{\mathrm{Hb}-\mathrm{P} 11}$ & $\mathrm{~T}_{\mathrm{Hb}-\mathrm{Pl} 2}$ & $\mathrm{~T}_{\mathrm{Hb} 1}$ \\
0.21 & $600-658$ & $601-659$ & $887-908$ \\
\hline
\end{tabular}

$\mathrm{T}_{\mathrm{Hb}-\mathrm{Pl} 1}$ : Holland and Blundy geothermometer, calculated with Schmidt (1992) pressures; $\mathrm{T}_{\mathrm{Hb}-\mathrm{Pl} 2}$ : Holland and Blundy geothermometer, calculated with Anderson and Smith (1995) pressures; $\mathrm{T}_{\mathrm{Hb} 1}$ : liquid-amphibole of Ridolfi et al. (2010).
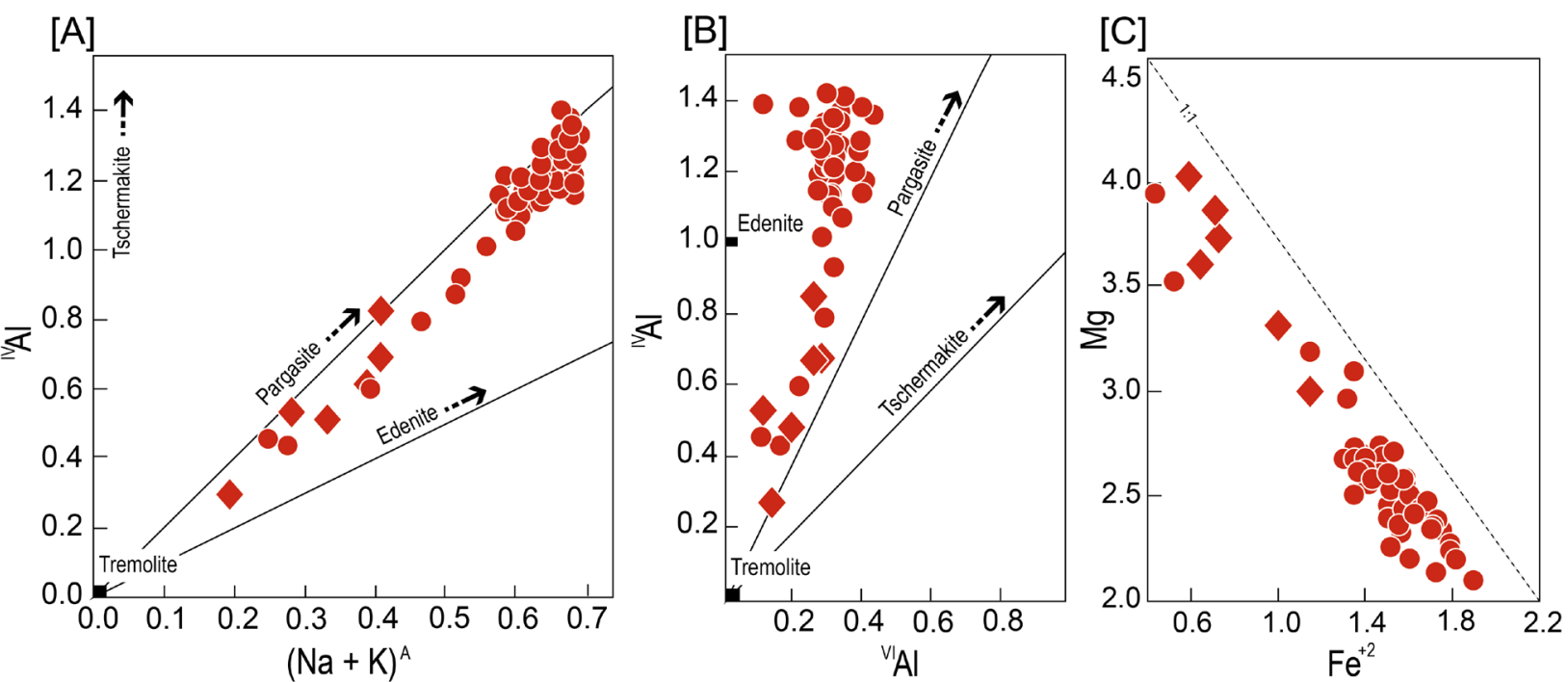

Core: circle; rim: diamond.

Figure 7. Chemical substitutions in the amphiboles, microgranular mafic enclaves of the Glória Norte Stock. (A) ${ }^{\mathrm{IV}} \mathrm{Al}$ and the occupancy rate of Site "A"; (B) ${ }^{\mathrm{IV}} \mathrm{Al}$ and ${ }^{\mathrm{VI}} \mathrm{Al}$; (C) $\mathrm{Fe}^{+2}$ and $\mathrm{Mg}$. Substitutions are named according to Spear (1981). 
monzonite amphibole, they indicate crystallization at high $\mathrm{fO}_{2}$ (Fig. 8B). The presence of the magnetite + titanite paragenesis in the MME reinforces the hypothesis of crystallization under oxidizing conditions (Wones 1989).

The mean pressure values calculated for GNS monzonite amphiboles are approximately $5 \mathrm{kbar}$, indicating crystallization at around $18 \mathrm{~km}$ depth. Using the Holland and Blundy (1994) and Ridolfi et al. (2010) geothermometers, the temperature of amphibole crystallization values obtained range between $615-747$ and $772-862^{\circ} \mathrm{C}$, respectively.

\section{DISCUSSION}

Amphiboles are very useful for the investigation of mafic magma genesis, especially the ultrapotassic ones, in which amphibole is an early crystallizing phase (Foley 1992, Conceição and Green 2004, Förster et al. 2017). Compositional variation in amphibole is strongly affected by changes in pressure, temperature, oxidation conditions, magma composition, and water activity (Scaillet and Evans 1999, Dalpé and Baker 2000, Rooney et al. 2011).

Experimental studies performed on amphiboles which crystallized in equilibrium with primitive basaltic magma have shown high mg\# values (0.83-0.75; Grove et al. 2003) as compared to amphiboles equilibrated with more evolved magmas, where lower values are observed (mg\# $\leq 0.65$; Alonso-Perez et al. 2009). The amphiboles of the MME show mg\# ranging between 0.48 and 0.84 ; these values correspond to those observed in primitive basaltic magmas and magmatic reequilibrium. This suggests that this mineral phase is a product of the early crystallization of these magmas (Hidalgo and Rooney 2010, Rooney et al. 2011). The lower mg\# values (below 0.65 ) of the studied MME amphiboles may be related to the physicochemical changes in the magmatic chamber (i.e., $\mathrm{P}, \mathrm{T}, \mathrm{fO}_{2}$ ) or crystallization in equilibrium with more evolved magmas (Ribeiro et al. 2016).

The equation $\left[\mathrm{Mg}_{\text {parental magma }}=1 /\left(1+\mathrm{K}_{\mathrm{D}}^{\mathrm{Fe} / \mathrm{Mg}} \times\left(\mathrm{Fe}_{\mathrm{T}} / \mathrm{Mg}\right)\right.\right.$ amphibole, $\mathrm{K}_{\mathrm{D}}^{\mathrm{Fe} / \mathrm{Mg}}=0.38$ ] by Alonso-Perez et al. (2009) was used to estimate the degree of differentiation of the mafic magma of the studied MME amphiboles. Primitive magmas, formed in the mantle, have $\mathrm{Mg} \#>0.70$, while the values of $\mathrm{Mg}^{\#}$ in evolved magma do not exceed 0.60 (Grove et al. 2003, 2012). Magmas in equilibrium with the studied amphiboles of the mafic enclaves have $\mathrm{Mg}^{\#}$ ranging from 0.71 to 0.93 (mean 0.78 ), indicating that these amphiboles represent early crystallized phases in mantle-derived magmas.

The compositions of the studied MME amphibole crystals, in particular the $\mathrm{Al}$ content, indicate that there are two groups of amphibole, respectively, crystallized at high- and low-pressures (Fig. 8A).

The highest pressure values correspond to lower $\mathrm{Si}$ and $\mathrm{Mg}$ content, and higher $\mathrm{Al}$ values, and should represent the earlier crystals crystallized at lower crustal levels, at $\sim 28 \mathrm{~km}$ (considering $1 \mathrm{kbar}=3.7 \mathrm{~km}$ of continental crust; Tulloch and Challis 2000). The lowest pressure values were obtained in $\mathrm{Si}$ - rich and $\mathrm{Al}$-poor crystals, and may represent a second generation of amphiboles or crystals reequilibrated under shallower crustal conditions.

In the Macururé Domain plutons, the interaction between mafic and felsic magmas has been pointed out by several authors as the process responsible for generating the mafic enclaves in these massifs (e.g., Conceição et al. 2016, Fontes et al. 2018, Lisboa et al. 2019). The following evidence, coming from our data, points out that the interaction between mafic and felsic magmas is physically possible: textural evidence (e.g., mafic mineral agglomerates); the compositional similarity between MME and the GNS amphiboles; similar crystallization temperature and liquidus temperature of the MME amphiboles and the GNS monzonite.

Yamaguchi et al. (2003) stated that the amphiboles formed at an early stage in mafic magma continue to crystallize after the interaction between magmas. The pre-interaction conditions can be obtained from early amphiboles and the reequilibrium conditions can be obtained from those phases which crystallized after the interaction. Our results suggest that the parental magmas of the MME were stored in deeper ( $28 \mathrm{~km})$ pressures, and the mixing with monzonitic magma was shallower $(\sim 18 \mathrm{~km})$ at crustal conditions. The interaction between these magmas occurred at temperatures ranging from 772 to
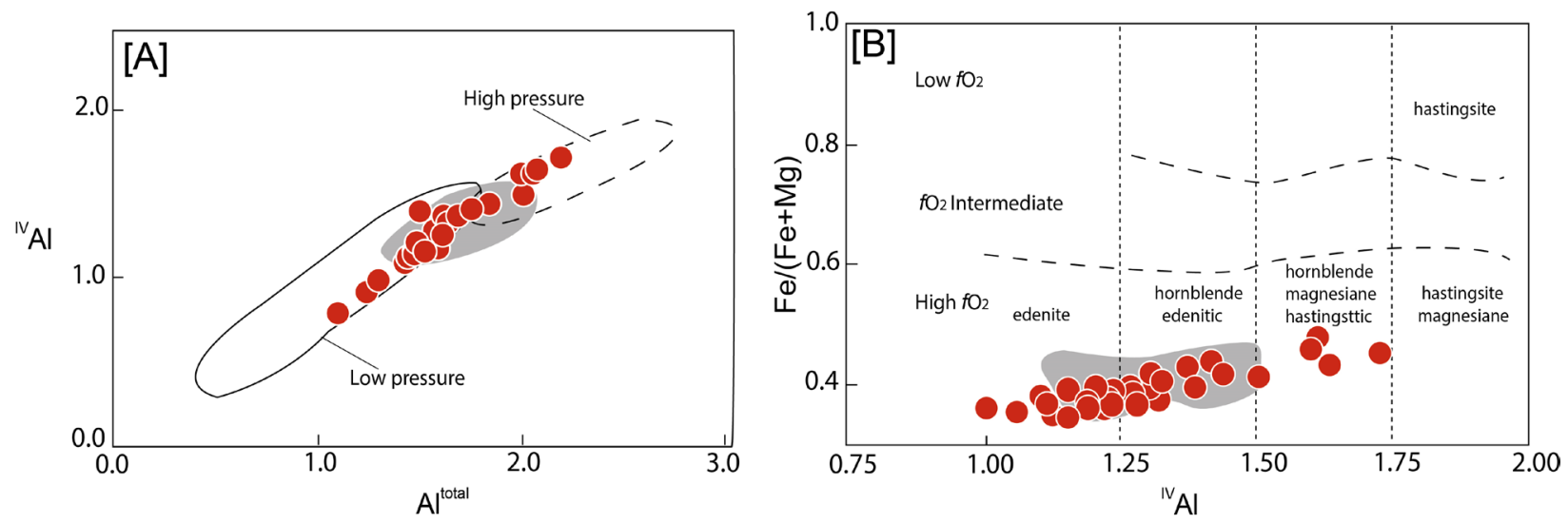

Figure 8. Diagrams showing the variation of chemical parameters and the conditions of pressure and oxygen fugacity for the crystallization of calcium amphiboles. (A) ${ }^{\mathrm{IV}} \mathrm{Al}$ versus $\mathrm{Al}^{\text {total }}$ diagram with high and low pressure, amphibole fields defined by Hammarstron and Zen (1986). (B) $\mathrm{Fe} /(\mathrm{Fe}+\mathrm{Mg})$ versus ${ }^{\mathrm{IV}} \mathrm{Al}$ diagram, showing fields with different conditions of oxygen fugacity $\left(f \mathrm{O}_{2}\right)$, according to Anderson and Smith (1995). The composition of grain cores corresponds to the circle; the grey area represents compositions of amphibole from monzonites of the Glória Norte Stock. 
$862^{\circ} \mathrm{C}$ as indicated by Ridolfi et al. (2010), considered by us as the best geothermometers for involving different chemical elements in the calculation.

\section{CONCLUSION}

The amphiboles of the microgranular mafic enclaves of the Glória Norte Stock are calcic and correspond to pargasite, edenite, magnesium-hornblende, and actinolite. They have varying Si contents (6.2-7.7 apuf) and $\mathrm{mg} \#$ ratio between 0.48 and 0.84 . The main important substitutions involve $\mathrm{Al}, \mathrm{Si}, \mathrm{Na}, \mathrm{Fe}$, and $\mathrm{Mg}$ (edenite and pargasite types) and reflect a decrease in temperature and an increase of $\mathrm{fO}_{2}$. The magmatic amphiboles of the GNS are edenite and magnesium-hornblende. They crystallize at 772 and $862^{\circ} \mathrm{C}$ and the mean pressure values are in the order of $5 \mathrm{kbar}$, indicating crystallization at around $18 \mathrm{~km}$ depth.

The identification of similar chemical compositions between amphiboles from the MME and host GSN, as well as the estimates of similar pressure and temperature obtained and the compositional similarity between amphibole from the MME and GNS monzonites all suggest chemical reequilibration between the magmas which originated the monzonites and the enclaves. The interaction between these magmas occurred under $\pm 5 \mathrm{kbar}$ pressure $(\sim 18 \mathrm{~km}$ depth$)$, with temperature ranging between 772 and $862^{\circ} \mathrm{C}$.

\section{ACKNOWLEDGMENTS}

The first author thanks the IFPB, Campus Picuí, for granting the removal for completion of the Doctorate in Geology at UFBA. The authors thank CNPq processes: 140117/2015-6 (VACL Doctorate grant), 311008/2017-8 (CNPq-PQ), 310391/2017-2 (CNPq-PQ), 405387/2016-4(CNPq-Universal 2016). We are grateful to the anonymous reviewers for the comments and suggestions that have improved considerably the original manuscript.

\section{ARTICLE INFORMATION}

Manuscript ID: 20190101. Received on: 09/28/2019. Approved on: 07/13/2020.

V.L. wrote the manuscript, prepared the figures and tables, and managed the corrections; H.C. contributed to field work, wrote, and revised the manuscript; M.R. contributed to and revised the manuscript; C.L. obtained and helped to process and discuss the mineral chemistry data; G.M. obtained and contributed to the processing and treatment of mineral chemistry data; A.L. helped with geological mapping and sampling. Competing interests: The authors declare no competing interests.

\section{REFERENCES}

Alonso-Perez R., Müntener O., Ulmer P. 2009. Igneous garnet and amphibole fractionation in the roots of island arcs: experimental constraints on andesitic liquids. Contributions to Mineralogy and Petrology, 157:541558. https://doi.org/10.1007/s00410-008-0351-8

Anderson J.L. 1996. Status of thermobarometry in granitic batholiths. Earth and Environmental Science Transactions of the Royal Society of Edinburgh, 87(1-2):125-138. https://doi.org/10.1017/S0263593300006544

Anderson J.L., Smith D.R. 1995. The effects of temperature and $\mathrm{fO}_{2}$ on the Al-in-hornblende barometer. American Mineralogist, 80(5-6):549-559. https://doi.org/10.2138/am-1995-5-614

Barbarin B., Didier J. 1992. Genesis and evolution of mafic microgranular enclaves through various types of interaction between coexisting felsic and mafic magmas. Earth and Environmental Science Transactions of the Royal Society of Edinburgh, 83(1-2):145-153. https://doi.org/10.1017/S0263593300007835

Baxter S., Feely M. 2002. Magma mixing and mingling textures in granitoids: examples from the Galway Granite, Connemara, Ireland. Mineralogy and Petrology, 76:63-74. https://doi.org/10.1007/s007100200032

Chivas A.R. 1982. Gechemical evidence for magmatic fluids in porphyry copper mineralization. Part I. Mafic silicates from the Koloula Igneous Complex. Contributions to Mineralogy and Petrology, 78:389-403. https:// doi.org/10.1007/BF00375201

Coltorti M., Bonadiman C., Faccini B., Grégoire M., O’Reilly S.Y., Powell W. 2007. Amphiboles from suprasubduction and intraplate lithospheric mantle. Lithos, 99(1-2):68-84. https://doi.org/10.1016/j.lithos.2007.05.009

Conceição J.A., Rosa M.L.S., Conceição H. 2016. Sienogranitos leucocráticos do Domínio Macururé, Sistema Orogênicos Sergipano, Nordeste do Brasil: Stock Glória Sul. Brazilian Journal of Geology, 46(1):6377. https://doi.org/10.1590/2317-4889201620150044

Conceição R.V., Green D.H. 2004. Derivation of potassic (shoshonitic) magmas by decompression melting of phlogopite+pargasite lherzolite. Lithos, 72(3-4):209-229. https://doi.org/10.1016/j.lithos.2003.09.003

DalpéC.,BakerD.R.2000.Experimentalinvestigation oflarge-ion-lithophileelement-, high-field-strength-element and rare-earth-element-partitioning between calcic amphibole and basaltic melt: the effects of pressure and oxygen fugacity. Contributions to Mineralogy and Petrology, 140:233-250. https://doi.org/10.1007/s004100000181

Davison I., Santos R.A. 1989. Tectonic evolution of the Sergipano fold belt, NE Brazil, during the Brasiliano orogeny. Precambrian Research, 45 (4):319342. https://doi.org/10.1016/0301-9268(89)90068-5

Deer W.A., Howie R.A., Zussman J. 1997. Rock-Forming Minerals. 2B. Double-Chain Silicates. London, Geological Society of London, 764 p.

Féménias O., Mercier J.C.C., Nkono C., Diot H., Berza T., Tatu M., Demaiffe D. 2006. Calcic amphibole growth and compositions in calc-alkaline magmas: Evidence from the Motru Dike Swarm (Southern Carpathians, Romania). American Mineralogist, 91(1):73-81. https://doi.org/10.2138/ am.2006.1869

Foley S.F. 1992. Petrological characterization of the source components of potassic magmas: geochemical and experimental constraints. Lithos, 28(36):187-204. https://doi.org/10.1016/0024-4937(92)90006-K

Fontes M.P., Conceição H.C., Rosa M.L.S., Lisboa V.A.C. 2018. Minettes do Stock monzonítico Glória Norte: Evidência de magmatismo ultrapotássico pós-orogênico, com assinatura de subducção, no Sistema Orogênico Sergipano. Geologia USP - Série Científica, 18(1):1-16. http://dx.doi. org/10.11606/issn.2316-9095.v18-133599

Förster M.W., Prelević D., Schmück H.R., Buhre S., Veter M., Mertz-Kraus R., Foley S.F., Jacob D.E. 2017. Melting and dynamic metasomatism of mixed harzburgite+ glimmerite mantle source: Implications for the genesis of orogenic potassic magmas. Chemical Geology, 455:182-191. http:// dx.doi.org/10.1016/j.chemgeo.2016.08.037

Green D.H., Ringwood A.E. 1963. Mineral assemblages in a model mantle composition. Journal of Geophysical Research, 68(3):937-945. https://doi. org/10.1029/JZ068i003p00937

Grove T.L., Elkins-Tanton L.T., Parman S.W., Chatterjee N., Muntener O. Gaetani G.A. 2003. Fractional crystallization and mantle-melting controls on calc-alkaline differentiation trends. Contributions to Mineralogy and Petrology, 145(5):515-533. https://doi.org/10.1007/s00410-003-0448-z 
Grove T.L., Till C.B., Krawczynski M.J. 2012. The role of $\mathrm{H}_{2} \mathrm{O}$ in subduction zone magmatism. Annual Review of Earth and Planetary Sciences, 40:413439. https://doi.org/10.1146/annurev-earth-042711-105310

Hammarstron J.M., Zen E. 1986. Aluminium in hornblende: an empirical igneous geobarometer. American Mineralogist, 71:1297-1313.

Hawthorne F.C. 1983. The crystal chemistry of the amphiboles. Canadian Mineralogist, 21(2):173-480.

Hendry D.A.F., Chivas A.R., Long J.V.P., Reed S.J.B. 1985. Chemical differences between minerals from mineralizing and barren intrusions from some North American porphyry copper deposits. Contributions to Mineralogy and Petrology, 89:317-329. https://doi.org/10.1007/BF00381554

Hidalgo P.J., Rooney T.O. 2010. Crystal fractionation processes at Baru volcano from the deep to shallow crust. Geochemistry, Geophysics, Geosystems, 11(12):1-29. https://doi.org/10.1029/2010GC003262

Holland T., Blundy J. 1994. Non-ideal interactions in calcic amphiboles and their bearing on amphibole-plagioclase thermometry. Contributions to Mineralogy and Petrology, 116:433-447. https://doi.org/10.1007/BF00310910

Hollister L.S., Grissom G.C., Peters E.K., Stowell H.H., Sisson V.B. 1987. Confirmation of the empirical correlation of $\mathrm{Al}$ in hornblende with pressure of solidification of calc-alkaline plutons. American Mineralogist, 72(3-4):231-239.

Johnson M.C., Rutherford M.J. 1989. Experimental calibration of the aluminum-in-hornblende geobarometer with application to Long Valley caldera (California) volcanic rocks. Geology, 17(9):837-841. https://doi. org/10.1130/0091-7613(1989)017\%3C0837:ECOTAI\%3E2.3.CO;2

Kawakatsu K., Yamaguchi Y. 1987. Successive zoning of amphiboles during progressive oxidation in the Daito-Yokota granitic complex, San-in belt, southwest Japan. Geochimica et Cosmochimica Acta, 51(3):535-540. https:// doi.org/10.1016/0016-7037(87)90067-6

Krawczynski M.J., Grove T.L., Behrens H. 2012. Amphibole stability in primitive arc magmas: effects of temperature, $\mathrm{H}_{2} \mathrm{O}$ content, and oxygen fugacity. Contributions to Mineralogy andPetrology, 164:317-339.https://doi.org/10.1007/s00410-012-0740-x

LeakeB.E.1971.Onaluminousandedenitichornblendes.MineralogicalMagazine, 38(296):389-407. https://doi.org/10.1180/minmag.1971.038.296.01

Leake B.E. 1978. Nomenclature of amphiboles. The Canadian Mineralogist, 16(4):501-520.

LeakeB.E.,WoolleyA.R.,Arps C.E.,BirchW.D., GilbertM.C., GriceJ.D.,Hawthorne F.C., Kato A., Kisch H.J., Krivovichev V.G., Linthout K., Laird J., Mandarino J. 1997. Report. Nomenclature of amphiboles: report of the subcommittee on amphiboles of the international mineralogical association commission on new minerals and mineral names. Mineralogical Magazine, 61:295-321.

Leandro M.V.S. 2018. Mineraloquímica de Rochas do Batólito Sienítico Itabuna, Sul do Estado da Bahia. Monografia, Departamento de Geologia, Universidade Federal de Sergipe, $67 \mathrm{p}$.

Lisboa V.A.C., Conceição H., Rosa M.L.S., Fernandes D.M. 2019. The onset of post-collisional magmatism in the Macururé Domain, Sergipano Orogenic System: The Glória Norte Stock. Journal of South American Earth Sciences, 89:173-188. https://doi.org/10.1016/j.jsames.2018.11.005

Martin R.F. 2007. Amphiboles in the igneous environment. Reviews in Mineralogy and Geochemistry, 67(1):323-358. https://doi.org/10.2138/rmg.2007.67.9

McDowell S.D., Willye P.J. 1971. Experimental studies of igneous rock series: the Kungnat complex of southwest Greenland. Journal of Geology, 79(2):173-194. https://doi.org/10.1086/627607

Mutch E.J.F., Blundy J.D., Tattitch B.C., Cooper F.J., Brooker R.A. 2016. An experimental study of amphibole stability in low-pressure granitic magmas and a revised Al-in-hornblende geobarometer. Contributions to Mineralogy and Petrology, 171:85. https://doi.org/10.1007/s00410-016-1298-9

Nandedkar R.H., Ulmer P., Müntener O. 2014. Fractional crystallization of primitive hydrous arc magmas: an experimental study at $0.7 \mathrm{GPa}$. Contributions to Mineralogy and Petrology, 167:1015. https://doi.org/10.1007/ s00410-014-1015-5

Oliveira E.P., Windley B.F., Araujo M.N.C. 2010. The Neoproterozoic Sergipano orogenic belt, NE Brazil: a complete plate tectonic cycle in western Gondwana. Precambrian Research, 181(1-4):64-84. https://doi. org/10.1016/j.precamres.2010.05.014

Pinho Neto M.A., Rosa M.L.S., Conceição H. 2019. Petrologia do Batólito Sítios Novos, Sistema Orogênico Sergipano, Província Borborema, NE do Brasil. Geologia USP. Série Científica, 19(2):135-150. https://doi. org/10.11606/issn.2316-9095.v19-152469

Piwinskii A.J. 1968. Experimental Studies of Igneous Rock Series Central Sierra Nevada Batholith, California. The Journal of Geology, 76(5):548-570. https://doi.org/10.1086/627359

Putirka K. 2016. Amphibole thermometers and barometers for igneous systems and some implications for eruption mechanisms of felsic magmas at arc volcanoes. American Mineralogist, 101(4):841-858. https://doi. org/10.2138/am-2016-5506

Ribeiro J.M., Maury R.C., Grégoire M. 2016. Are Adakites slab melts or high-pressure fractionated mantle melts? Journal of Petrology, 57(5):839862. https://doi.org/10.1093/petrology/egw023

Ridolfi F., Renzulli A., Puerini M. 2010. Stability and chemical equilibrium of amphibole in calc-alkaline magmas: an overview, new thermobarometric formulations and application to subduction-related volcanoes. Contributions to Mineralogy and Petrology, 160:45-66. https://doi.org/10.1007/s00410-009-0465-7

Rooney T.O., Franceschi P., Hall C.M. 2011. Water-saturated magmas in the Panama Canal region: a precursor to adakite-like magma generation? Contributions to Mineralogy and Petrology, 161:373-388. https://doi. org/10.1007/s00410-010-0537-8

Şahin S.Y., Orgun Y., Gungor Y., Goker A.F., Gultekin A.H., Karacik Z. 2010. Mineral and Whole-rock Geochemistry of the Kestanbol Granitoid (EzineÇanakkale) and its Mafic Microgranular Enclaves in Northwestern Anatolia: Evidence of Felsic and Mafic Interaction. Turkish Journal of Earth Sciences, 19:101-122. https://doi.org/10.3906/yer-0809-3

Samaniego P., Robin C., Chazot G., Bourdon E., Cotten J. 2010. Evolving metasomatic agent in the Northern Andean subduction zone, deduced from magma composition of the long-lived Pichincha volcanic complex (Ecuador). Contributions to Mineralogy and Petrology, 160(2):239-260. https://doi.org/10.1007/s00410-009-0475-5

Sato H., Nakada S., Fujii T., Nakamura M., Suzuki-Kamata K. 1999. Groundmass pargasite in the 1991-1995 dacite of Unzen volcano: phase stability experiments and volcanological implications. Journal of Volcanology and Geothermal Research, 89(1):197-212. https://doi.org/10.1016/S0377-0273(98)00132-2

Scaillet B., Evans B.W. 1999. The 15 June 1991 eruption of Mount Pinatubo. I. Phase equilibria and pre-eruption $\mathrm{P}-\mathrm{T}-\mathrm{fO}_{2}-\mathrm{fH}_{2} \mathrm{O}$ conditions of the dacite magma. Journal of Petrology, 40(3):381-411. https://doi.org/10.1093/petroj/40.3.381

SchmidtM.W. 1992.Amphibole composition in tonalite as a function of pressure: an experimental calibration of the $\mathrm{Al}$-in-hornblende barometer. Contributions to Mineralogy and Petrology, 110:304-310. https://doi.org/10.1007/BF00310745

Sial A.N., Ferreira V.P., Fallick A.E., Cruz M.J.M. 1998. Amphibole-rich clots in calc-alkalic granitoids in the Borborema province, northeastern Brazil. Journal of South American Earth Sciences, 11(5):457-471. https://doi. org/10.1016/S0895-9811(98)00034-0

Silva Filho A.F., Guimarães I.P., Silva M.R.R. 1992. Utilização de granitóides na definição de domínios tectônicos; aplicação no lado oriental do Sistema de Dobramento Sergipano. In: Congresso Brasileiro de Geologia, 37., 1992. Boletim de Resumos Expandidos.

Spear F.S. 1981. An experimental study of hornblende stability and compositional variability in amphibolite. American Journal of Science, 281:697-734. https://doi.org/10.2475/ajs.281.6.697

Stout J.H. 1972. Phase petrology and mineral chemistry of coexisting amphiboles from Telemark, Norway. Journal of Petrology, 13(1):99-145. https://doi.org/10.1093/petrology/13.1.99

Tulloch A.J., Challis G.A. 2000. Emplacement depths of PaleozoicMesozoic plutons from western New Zealand estimated by hornblende-AI geobarometry. New Zealand Journal of Geology and Geophysics, 43(4):555567. https://doi.org/10.1080/00288306.2000.9514908

Wones D.R. 1989. Significance of the assemblage titanite+ magnetite+ quartz in granitic rocks. American Mineralogist, 74(7-8):744-749.

Yamaguchi Y. 1985. Hornblende-cummingtonite and hornblende-aclinolite intergowths from the Koyama calc-alkaline intrusion, Susa, southwest Japan. American Mineralogist, 70(9-10):980-986.

Yamaguchi Y., Wada H., Ohta Y., Harayama S. 2003. Amphibole zoning, a record of progressive oxidation during crystallization of mafic microgranular enclaves in the Kurobegawa Granitic Pluton. Journal of Mineralogical and Petrological Sciences, 98(4):151-155. https://doi.org/10.2465/jmps.98.151 